\title{
Re-Thinking Mining Waste through an Integrative Approach Led by Circular Economy Aspirations
}

\author{
Maedeh Tayebi-Khorami $®$, Mansour Edraki, Glen Corder and Artem Golev* \\ Centre for Mined Land Rehabilitation, Sustainable Minerals Institute, The University of Queensland, \\ St Lucia QLD 4072, Australia; m.tayebikhorami@uq.edu.au (M.T.-K.); m.edraki@cmlr.uq.edu.au (M.E.); \\ g.corder@smi.uq.edu.au (G.C.) \\ * Correspondence: a.golev@uq.edu.au
}

Received: 5 April 2019; Accepted: 9 May 2019; Published: 10 May 2019

\begin{abstract}
Mining wastes, particularly in the form of waste rocks and tailings, can have major social and environmental impacts. There is a need for comprehensive long-term strategies for transforming the mining industry to move toward zero environmental footprint. "How can the mining industry create new economic value, minimise its social and environmental impacts and diminish liability from mining waste?" This would require cross-disciplinary skills, across the social, environmental, technical, legal, regulatory, and economic domains, to produce innovative solutions. The aim of this paper is to review the current knowledge across these domains and integrate them in a new approach for exploiting or "re-thinking" mining wastes. This approach includes five key areas of social dimensions, geoenvironmental aspects, geometallurgy specifications, economic drivers and legal implications for improved environmental outcomes, and circular economy aspirations, which are aligned with the 10 principles of the International Council on Mining and Metals (ICMM). Applying circular economy thinking to mining waste presents a major opportunity to reduce the liability and increase the value of waste materials arising from mining and processing operations.
\end{abstract}

Keywords: sustainable development; tailings management; industrial ecology; sustainable resource management; mining waste; circular economy

\section{Introduction}

Each year, mining operations generate large volumes of mining waste. According to the Mining, Minerals, and Sustainable Development Project (MMSD), there are approximately 3500 active mining waste facilities worldwide, consisting of waste rock dumps and tailing dams. The estimated worldwide generation of solid wastes from the primary production of mineral and metal commodities is over 100 billion tonnes per year and can range from several times the mass of the valuable element, such as iron and aluminium ores, up to millions of times for some scarce elements such as gold ore [1]. This large amount of mining waste can have major environmental impacts and require appropriate management strategies both in the short- and long-term [2]. In addition, increasing demand for essential metals is leading to the extraction and development of complex finer-grained low-grade orebodies. The mining of lower grade and/or complex ores will produce greater quantities of tailings per ton of product and will also increase the fines content of the tailings [3]. If not managed properly, mining waste can generate significant pollution, both through air pathways (dust and gas emissions) and water leaching (acid mine drainage) [4]. Moreover, failure to manage can result in costly catastrophic consequences. Recent events, such as the Brumadinho tailings dam failure in Brazil, have heightened the attention of the industry and society to the catastrophic impacts of mining waste when failure of tailings management systems occurs. One way to better manage mine waste is to reduce its generation 
from mining, such as transitioning from open-pit surface operations to underground mining by the development of more powerful and efficient underground equipment [5].

The environmental, economic, and social impacts of mining waste indicate that the mining industry needs to re-think waste management. This re-thinking will require expertise from many disciplines to make a transformational change to how the mining industry and its stakeholders manage and utilise mining waste in current operations and future projects. Potential solutions should draw on existing approaches, such as cleaner production, by-products from waste, re-engineering of processes, closed-loop systems, and product stewardship [1].

This paper aims to assess current management frameworks and the application of mining waste management strategies, and to determine current gaps and challenges. It also highlights the benefits of an integrative approach for exploiting mining waste across the social, environmental, technical, legal, regulatory, and economic domains.

\section{Sustainable Development of Mining Waste}

Over the last few decades, several approaches have emerged that aim to include sustainability aspects across the mining life cycle [6]. Several industry organisations and companies have implemented sustainability principles and strategies for establishing commitment to resource development in a socially and environmentally responsible manner. One such organisation, the International Council on Mining and Metals (ICMM), has 10 principles for effective sustainable development, presented in Table 1 [7].

Table 1. Sustainable development principles of ICMM.

\begin{tabular}{cc}
\hline $\mathbf{1}$ & Ethical business and sound governance \\
\hline 2 & Integrate sustainable development in decision-making \\
\hline 3 & Respect for human rights \\
\hline $\mathbf{4}$ & Effective risk management strategies \\
\hline $\mathbf{5}$ & Health and safety performance \\
\hline $\mathbf{6}$ & Environmental performance \\
\hline $\mathbf{7}$ & Conservation of biodiversity and land-use planning \\
\hline $\mathbf{9}$ & Responsible design, use, reuse, recycling, and disposal of materials \\
\hline $\mathbf{1 0}$ & Social contribution \\
\hline
\end{tabular}

These principles are similar to international sustainable management standards, including the Rio Declaration [8], Global Reporting Initiative [9], World Bank Operational Guidelines, the International Labour Organization (ILO) Conventions, and the Voluntary Principles on Security and Human Rights [7]. These 10 principles cover many topics associated with sustainability, although there is no uniform approach that allows the industry to better integrate sustainability into the design process. Ideally, a sustainability framework should connect corporate and operational level activities and engage with technical professionals [10].

In this regard, we have identified five key areas, which are aligned with the 10 ICMM principles, that will cover the most important aspects for improved environmental outcomes, and circular economy aspirations. We believe that a dynamic interaction across these five areas will drive the mindset change for re-thinking mining wastes. It includes social dimensions, geoenvironmental aspects, geometallurgy specifications, economic drivers, and legal implications (Figure 1). At its core is the overarching question: "How can the mining industry create new economic value, minimise its social and environmental impacts and diminish liability from mining waste?" To find potential solutions to this question, the following guiding questions should be addressed in the following order: 
- Social dimensions: What are the local, regional, and global societal dimensions related to managing mining waste?

- Geoenvironmental aspects: What are the spatial and temporal geoenvironmental impacts resulting from mining waste, and how can potential liabilities be prevented or substantially mitigated?

- Geometallurgy specifications: What are the geometallurgical properties to create additional value and improve environmental outcomes in waste from mining and mineral processing?

- Economic drivers and legal implications: How and what economic drivers should lead the changes in regulatory systems, to transform business approaches for creating value, diminishing risk and drastically mitigating liabilities from mining waste?

- Circular economy aspirations: How can the mining industry assess and quantify their contribution to the circular economy?

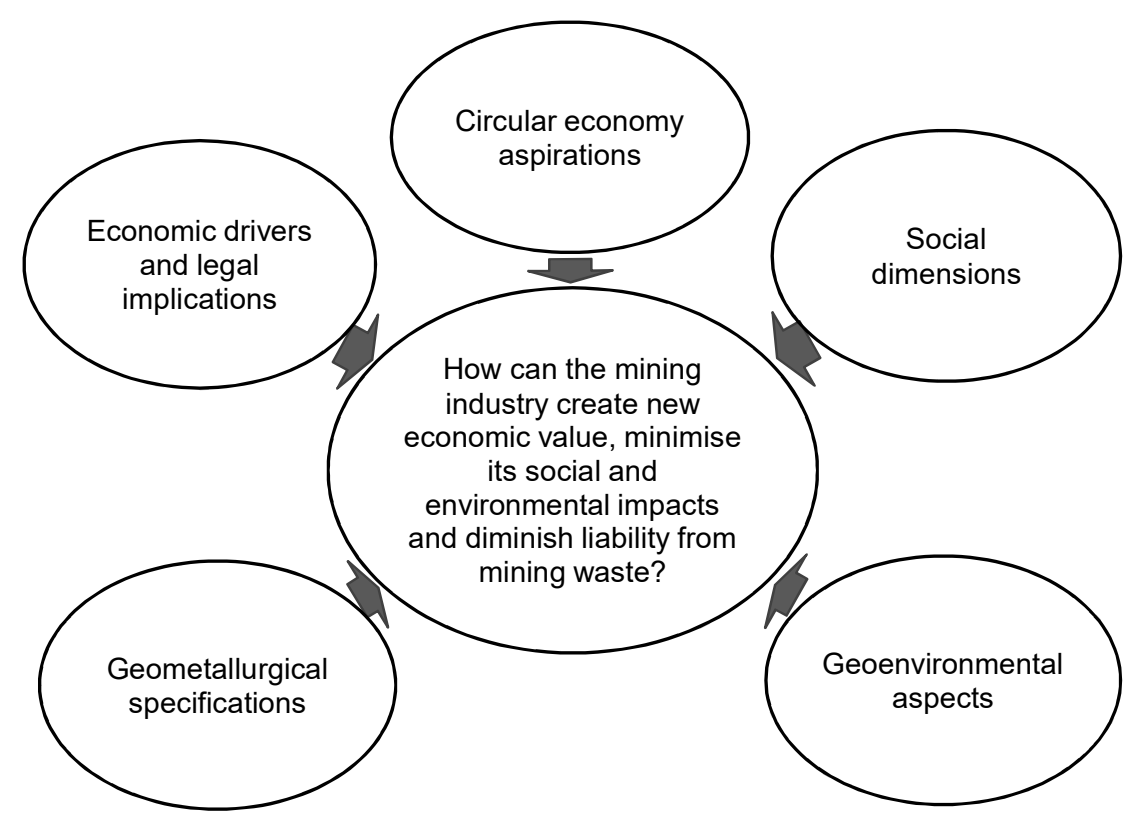

Figure 1. Key areas of an integrative approach for mining waste.

By taking this approach there will be a far greater chance that social dimensions and expectations will be achieved within the technical, regulatory, and economic constraints, while ensuring potential outcomes meet the aims and desires of the circular economy. If all of this is achieved, then the social expectations, which are closely aligned with the aspirations of the circular economy, should be broadly met.

\section{Five Areas of Integrative Approach}

In this section, the key aspects of practice in the five areas of an integrative approach are reviewed. These reviews provide a basis for developing the connections across the five areas.

\subsection{Social Dimensions}

Mining companies have had a long reputation for social responsibility [11], however, the costs of community conflict remain poorly understood. A recent study investigated the cost of conflict between the community and companies in the extractive sector, and found that the majority of mining and gas companies do not identify the full range of costs of conflict with local communities [12]. Conflict between an extractive company and the community is often triggered by the environmental impacts of company operations [12]. Conflict therefore acts as a means by which environmental and social risks are translated into actual business cost [13]. 
Esteves et al. [14] noted the importance of social impact assessment (SIA) in managing issues associated with mining and development, and described a mechanism for identifying, assessing, and managing the social impacts of mining in a systematic manner. SIAs can be used not just for understanding and resolving existing conflicts, but also for preventing conflicts [15], particularly by tracking changes in economic and social conditions over time [16].

Kemp and Vanclay [17] examined the inclusion of human rights in impact assessments and noted that the discourse surrounding a company's human rights related responsibilities is framed around avoiding or minimising harm, and does not extend to the development of benefits or shared value. Similarly, within the mining industry, the concept of "social license to operate" is viewed and applied as a way of reducing opposition to industry, rather than an opportunity for a company to collaborate with community to create an agenda that would satisfy the community's desire for development and the company's desire for a profitable and sustainable business [18].

One area that poses a substantial risk to the environment, human rights, and a company's social licence to operate is the disposal of mining and mineral processing wastes. Franks et al. [19] developed a set of seven principles based on sustainable development to guide decision making in regard to mining waste disposal, including: (1) Mining and mineral processing wastes should be managed in a way that is physically and chemically stable; (2) the waste that interacts with the environment should be inert; (3) waste that is not inert should be isolated in a form that limits interaction and subsequent mobilisation; (4) the waste should be contained, i.e., geographically bounded and managed with a minimal footprint that limits interaction with the surrounding environment; (5) the waste should be managed in a manner that considers local environmental and social conditions of each location; (6) the waste should be managed in a way that minimises water and energy use and the need to actively manage wastes after mine closure; and (7) preference should be given to technologies that improve the impacts of waste disposal on society and the environment and provide opportunities for re-use should they be pursued [19].

\subsection{Geoenvironmental Aspects}

Mine waste facilities mainly consist of waste rocks dumps and tailings dams, requiring appropriate management both in the short- and long-term.

\subsubsection{Waste Rocks Dumps}

Mining operations produce large quantities of waste rocks, which often has little or no valuable minerals. Waste rocks contain coarse, crushed, or blocky material covering a range of sizes, from very large rocks to fine particles. The current practices of dumping waste rocks by trucks, or draglines in the case of coal mines, create very large layered structures with preferential flow paths, which are conducive for the generation of acid and metalliferous drainage (AMD)—a significant challenge to mine owners, regulators, and other stakeholders. AMD, generated through the oxidation of sulphide minerals (mainly pyrite) in waste rocks, comprises poor-quality leachate typically characterised by acidic $\mathrm{pH}$ and high concentrations of sulphate, iron, and heavy metals.

Sometimes, due to the presence of carbonates or other gangue minerals, reactions do not lead to acidic conditions, however, they can still result in poor-quality drainage with high concentrations of sulphate, metals and metalloids (e.g., arsenic), and salts referred to as neutral or saline drainage. AMD can be detrimental to aquatic ecosystems and possibly human health, impact groundwater quality and limit the downstream water use, and results in long-term environmental liabilities. The measures to counter this, often only partially, include mined land rehabilitation programs and the installation of expensive water treatment systems, and require long-term monitoring of the impacted area and surrounding environment.

Remediation of acid producing mine waste and treatment of mine water can be costly. Management costs for AMD have been estimated globally at approximately US\$ 1.5 billion per year [20], while the overall environmental liabilities are estimated to be in excess of US $\$ 100$ billion [21]. Integration of an 
AMD management plan, from the early phases of exploration until final closure, can help to decrease the environmental impacts. This requires the commitment of the whole operation from mine planners to the sustainability managers, and it must be incorporated into the mine's financial models.

With detailed geological, mineralogical, and geochemical assessments at an early stage in the development of ore deposits, it is possible to develop a resource block model for waste rocks to allow selective handling of waste. This will substantially reduce the overall cost of the monitoring and disposal of AMD generating waste. The common practices used in integrating the AMD management plan into mine operations include, for example, selective mining and placement of sulphide waste, encapsulation of potentially acid-producing (PAF) materials, potential layering and blending during the construction of waste rocks dumps, dispose of PAF materials in the backfills, isolating the acid-producing pit floor using barriers, and preventing the interaction of groundwater with the pit floor [22].

Various low cost waste products have been used to manage AMD [23]. Fly ash has been used to help neutralise AMD, improve the quality of degraded soils, and as a part of a cover system designed to isolate potentially hazardous mining waste. However, a lack of information on the practical use of coal combustion by-products (including fly ash) and a lack of guidelines and regulations for their use has limited their application in mine site rehabilitation and backfilling [24]. Waste rocks can also be a resource of minerals and metals, or have other applications at the mine site or elsewhere, such as backfill for open voids and underground mines, landscaping, capping for waste facilities, soil components and soil additives (e.g., for neutralizing infertile alkaline agricultural soils), aggregate and construction materials, and alternative raw materials for cement and concrete [20].

\subsubsection{Tailings Dams}

Volumetrically, mine tailings impoundments are among the largest man-made structures in the world [25]. Furthermore, tailings dam failures account for the major mining-related environmental disasters [26]. A major recent failure happened in January 2019 when Vale's iron ore tailings dam in Brumadinho, Brazil collapsed and killed at least 206 people. Another catastrophic event happened in November 2015 when a tailings dam at the Samarco Mine, Brazil, collapsed, releasing more than 43.7 million cubic meters of water and mine waste, and the resulting mudflow reached the Atlantic coast through the Doce River, along more than $500 \mathrm{~km}$ of the river course. In September 2008, 277 people died in an accident caused by iron ore tailings release from a dam break in Shanxi Province, China [27].

Similar to waste rocks dumps, tailings may generate AMD and, apart from the catastrophic failure of dam walls, may pose chronic environmental and human health issues due to the dispersion of contaminants by dust and seepage. Tailings may also contain mineral processing reagents, including salts and cyanide.

Reactive strategies, such as remediation of tailings solids or tailings seepage water, can pose long-term legacies for companies, governments, and society after mine closure, and do not meet community expectations. Edraki et al. [28] compared different tailings disposal methods, including conventional disposal; paste and thickened tailings; tailings reuse, recycling, and reprocessing; and proactive management. The review of different tailings disposal methods indicated that an integrative, proactive approach to tailings management is needed for improved, environmental, social, and economic outcomes. Such an approach would involve using geo-metallurgical data from the orebody to predict the composition of tailings produced by different processing scenarios. The implications for environmental management and closure can then be predicted earlier and considered as part of the mine plan. The tailings revegetation and capping strategies for two Australian tailings storage facilities which had failed to prevent tailings seepage for several years after mine closure were discussed in [29] and [30].

There is also an increasing interest in new technologies to recycle and utilize mine tailings more effectively. For example, the alkali-activation of some mine tailings allows binders with sufficient compressive strength to be used as a mine backfill or raw material in the construction industry. 
The application of untreated tailings that contain trace elements in civil engineering projects is hindered by the potential leaching of some toxic elements. However, such materials can be used with cementitious binders, such as Portland cement, slag, lime, and gypsum [31-34]. Kim et al. [35] studied the feasibility of tailings with no pre-treatment in cement based low-strength materials. Liu et al. [36] fabricated a new type of porous ceramics by a conventional ceramic sintering process using lead-zinc mine tailings and fly ash as the raw material. Taha et al. [37] present a feasible approach of reusing the tailings from waste rock residual coal to produce ecofriendly fired bricks. An advantage associated with the re-use of tailings is that, as they have already undergone industrial processes, they usually exhibit good homogeneity and fine particle sizes. Other efforts to recycle mining waste have been described elsewhere [38].

Desulphurisation has been considered as an alternative method to avoid formation of AMD [39]. Depyritised tailings have low sulphide content so that they are not acid generating. The iron sulphide (pyrite) particles could be concentrated, and then back-filled in mines or deposited separately. Depyritised tailings could also potentially be used as cover on mine waste storage facilities. An approach where conventional tailings are separated by flotation into a sulphide-rich and a largely benign fraction of tailings has also been proposed [40].

\subsection{Geometallurgy Specifications}

The traditional approach for ore body evaluation focuses on the in-situ tonnes and grade as well as testwork to estimate recovery. However, with more complex and refractory ore bodies being exploited, there is an increasing emphasis on risk management and cost efficiency. The geometallurgical approach directly addresses this by using 3D block models that display the distribution of key metallurgical parameters through the orebody [41]. An effective geometallurgical model integrates the important geological information, including geological, geotechnical, geochemical, and mineralogical data, with metallurgical test work results.

Geometallurgy not only involves the integration of geological, mining, and metallurgical fields, but it can also be expanded to include environmental and economic information to produce a block model that can be used to obtain the best outcome in terms of plant response and plant sustainability [42]. There are several benefits in applying geometallurgical theory to reduce the technological and financial risk of a project. This can be through plant design, production forecasting, optimisation of the water balance, as well as modelling of tailings storage facilities and predicting the settlement behaviour and stability of different mine waste types under different conditions. Geometallurgy is also a useful method to better understand mining waste and the potential hazards from acid rock drainage [43].

Dunham and Vann [44] and Vann, et al. [45] outline a broad "whole-of-value-chain" view through integration of geology, mine planning, operational design, metallurgy, marketing, and environmental management to improve or maximise the economic value of mining projects and operations. Bye [46] discussed some industry case studies that demonstrate strategies for gaining value from geometallurgical initiatives. This highlighted that the geometallurgical approach is moving away from factored ore reserves to data-rich block models and in doing so provides reliable information for mining, metallurgical, and environmental considerations. Louwrens et al. [47] and Louwrens et al. [47] studied the usage of geometallurgical principles and methodologies for reprocessing of the Ernest Henry ( $\mathrm{Cu}-\mathrm{Au})$ tailings storage facility in North-West Queensland, Australia. They established a new standard method of economic evaluation of the potential of reprocessing the tailings material. Edraki et al. [48] produced new tailings management models to predict the properties of tailings generated under various processing scenarios. These results were used to determine the implications for environmental management. Tungpalan et al. [49] developed a method to assess the variability of an ore deposit and its influence on metallurgical performance. Effective sample selection for mineralogical characterisation was used to link geometallurgy to circuit simulation. The drill core samples were classified according to the geological and mineralogical factors. Results of the classification were used to decide where more samples were needed, and which samples should undergo a more detailed 
analysis by a geologist. The improved characterisation of the ore body was used in a circuit simulation to predict the characteristics of the final concentrate and tailings. The knowledge of the characteristics of the concentrate and tailings can be used in mine planning so that parts of the ore body can be targeted for extraction that balance revenue from mineral recovery with tailings management costs.

A treatment methodology to improve the selectivity of enargite removal from a copper-gold ore and reduce arsenic content in the tailings using process mineralogy was proposed by Tayebi-Khorami et al. [50]. This methodology involved two steps:

- A de-sliming stage prior to the flotation process, where fine liberated enargite can be separated from the flotation feed; and

- A fine treatment stage, where the fine gangue minerals can be separated, the copper can be recovered, and the arsenic can be safely stored.

The separation of the fine enargite results in the exclusion of arsenic from the tailings.

\subsection{Economic Drivers and Legal Implications}

Economic drivers and legal implications play an important, if not critical, role in establishing new paradigms and allowing innovative approaches to be implemented. Without a proper understanding of the economics as well as the legislative and regulatory context, technically feasible solutions that deliver better outcomes can fail.

A pivotal report 30 years ago was "Our Common Future" by the World Commission on Environment and Development [51], which defined sustainable development as "development that meets the needs of the present without compromising the ability of future generations to meet their own needs". This highlights the concept of inter-generational equity relevant to mining legacies as well as economic development and legal requirements. While mineral and energy resources are obviously extracted without being replaced, it is possible to mitigate impacts and generate wealth for governments and communities from mining. Such examples include investing in community development and the regeneration of mined landscapes to create positive legacies.

The drive toward a more sustainable society will result in better worldwide standards and global regulatory and governance bodies. These will cover the spectrum of industrial and environmental impacts of all stages of a product's life cycle [52]. Better life-of-mine planning can reduce the amount of waste generated and help prevent acid mine drainage containing high concentrations of metals, and most likely reduce overall project costs [53].

With increasing reuse and recycling, resources will last longer and deliver on the aims of the circular economy. This transition requires fundamental changes, including appropriate infrastructure, regulation and legislation, and competitive economics. Recycling could be made mandatory for private and commercial companies, while product design should allow for easy dismantling and metals extraction, e.g., from computers and other electronic products [52].

Aspects related to licence to operate, social factors, and the regulatory environment depend heavily on the project jurisdiction. As a result, there is a strong contextual component in developing a new mining project that does not directly relate to technical aspects, but can affect the financial aspects [54].

\subsection{Circular Economy Aspirations}

The mining sector is represented mainly by linear activities, being the major supplier of resources to modern society, nevertheless the concept of circular economy can help to improve the sector's sustainability performance [55]. The aim would be to optimise the total material cycle from mining to manufacturing and to extend the product use phase, including the reuse and recycling of any waste streams arising in industrial and consumer activities to ensure overall resource efficiency and resilience [56]. Eco-efficiency and resilience have been identified as key characteristics of a sustainable mining operation, where optimising extraction and minimising the amount of valuable material in the 
waste would help to address problems, such as a declining ore grade, decreasing economic viability, and increasing mining legacies [4].

Under the conventional linear economy model, the current trends in mining, such as decreasing ore grades and higher tonnage rates, would continue escalating the problem with mining waste, and its associated inherent risks. Where feasible, replacing open cut mining with underground mining will make a significant reduction in waste generation. Alternative approaches, whether they relate to better waste disposal techniques, such as paste and thickened tailings, better mined land rehabilitation practices, or waste rocks and tailings reuse, recycling, and reprocessing, are urgently needed. In fact, the industry will need to move progressively to "closing the loop" strategies, which will dramatically reduce the quantities of wastes [1].

The circular economy articulates the importance of closed loop systems which reduce the need for the extraction and processing of new resources. This can be extended further to the overall impact from mining activities, with a particular focus on "getting more from less". As such, within the mining and metals sector, following the $3 \mathrm{R}$ waste reducing principle (reduce, reuse, recycle) can make a significant contribution [57]. This includes examples across two categories:

(a) Circular economy sensu stricto:

- Improving water and material reuse through cyclic systems and innovative technologies;

- Maximizing reuse of waste and by-products;

- Collaborating with the manufacturing sector to design adaptable and easy-to-repair products;

- Better marking of materials and alloys to aid identification at end-of-life and allow subsequent reuse and recycling.

(b) Efficiency measures as part of the circular economy in a wider sense:

- limiting the use of raw materials and balancing supply and demand;

- Improving recovery rates in mining and mineral processing;

- Minimizing waste generation such as tailings, gas emissions, and waste water;

- Developing feasible options for lower grade ores;

- Extending the life of a resource, material, product, or service through better planning for future applications and reuse [52].

Several different strategies for limiting mining waste and/or the associated environmental impacts have been classified by their ability to generate additional economic value and potentially decrease the environmental legacy of mining operations [58]. However, the best outcomes can be achieved with proactive waste management, which would combine ore body characterisation, mine planning, ore processing, waste disposal, re-processing, recycling and reuse, and finally land rehabilitation in one integrative approach [59]. This would be a crucial contribution that the mining industry can make towards the circular economy.

Another important and inherent part of the circular economy approach is the introduction of disruptive innovations [60]. In mining these can include, for example, the integration of tailings reprocessing with mined land rehabilitation, and using the post-mine landscape for new economic activities and development. Two recent examples of such innovative thinking originate from North Queensland in Australia. Kidston Renewable (solar and hydro) Energy Hub has been developed on the historic gold mine site, with the reuse of two open pits at different elevation levels as part of energy generation and storage [61]. The New Century mine project involves reviving zinc concentrate production after mine closure, based on the reprocessing of historic tailings and taking responsibility for the final rehabilitation of the mine site [62]. 


\section{Re-Thinking Mining Waste}

The mining industry is essential to global economic and social development, and it will continue to be the major resource supplier to our society for the foreseeable future [63]. A strong transition towards recycling and circularity is necessary, but requires some fundamental changes, including appropriate infrastructure, legislation, and favourable economics.

Despite the advancements in tailings management in the last few decades, there is a lack of optimal scenarios for mining waste that deliver overall sustainable societal benefits. Novel initiatives for dealing with mining waste and evidence-based best-practice guidelines for minimising environmental and human health risks are essential to reverse this trend. A transformational perspective to mining waste is necessary and should include a multidisciplinary and integrative approach for exploiting mining waste to create new economic value and move toward a zero environmental footprint. These elements speak to the aspirations of the circular economy and drive down impacts with residual waste management.

Applying circular economy thinking to mining waste presents a major opportunity to reduce the liability and increase the value of mining waste. However, many obstacles exist, such as current regulatory regimes and societal acceptance of products made from mining waste. Solutions to these obstacles are required across and between social, geoenvironmental, geometallurgical, engineering, economic, and legal/regulatory fields. By following the circular economy aspirations, the mining industry and regulators will engage in the full life cycle of projects, including final residual wastes, utilising natural cycles and transformations of metals in the environment, and, importantly, creating resilience to resources cycles (i.e., better responses to changes in the global supply and demand for different resources).

Knowledge of the industries that would use the products created with mining waste and what is required to connect the mining industry with downstream users is, however, far less developed. A greater understanding of the impact of companies that are likely to produce or use products from mining waste as well as the social perception and acceptability of those products is important and can only be properly determined by applying a multidisciplinary approach.

Human health and environmental impacts of metal toxicity will also be critical in determining whether products made from mining waste (e.g., construction materials) are safe. Effective regulation will be relevant to the design of new regulatory regimes that promote circular economy thinking and the management of mining waste in a way that increases its value and reduces risk posed by the waste.

A new approach driven by circular economy aspirations and sustainable development ideals, adhering to the highest available resource value principles, will help increase the value of mining waste. Specifically, it would help determine optimal scenarios for mining waste that would deliver overall societal benefits, notably including economic benefits for the industry and reducing the liabilities from mining legacies. These optimal scenarios are the catalyst for developing innovative processes, underpinned by rigorous, integrated analysis across the geometallurgical, geoenvironmental, engineering, social, legal, regulatory, and economic disciplines. The success would be measured by the delivery of transformational outcomes for the industry and government, including novel initiatives for dealing with mining waste and evidence-based best practice guidelines for minimising environmental and health risks.

\section{Conclusions}

In this paper, we identified and reviewed five key areas, which can form an integrative approach for exploiting or "re-thinking" mining wastes, framed around the circular economy. These include social dimensions, geoenvironmental aspects, geometallurgy specifications, economic drivers, and legal implications. While this dynamic and conceptual approach will be helpful for re-thinking mining waste, much work is still necessary in the research and development phases to identify efficient and effective solutions in each key area. Importantly, feasible solutions, like any credible sustainable 
development outcome, will require contextual knowledge for each mining operation and/or mining project under consideration.

Author Contributions: M.T.-K. led the writing—original draft as well as contributing to the conceptualization and methodology. M.E., G.C. and A.G. were involved in the conceptualization and methodology, and contributed to the writing, review, and editing.

Funding: This research received no external funding.

Conflicts of Interest: The authors declare no conflict of interest.

\section{References}

1. Rankin, W.J. Towards zero waste. AusIMM Bull. 2015, 2015, 32-37.

2. Adiansyah, J.S.; Rosano, M.; Vink, S.; Keir, G. A framework for a sustainable approach to mine tailings management: Disposal strategies. J. Clean Prod. 2015, 108, 1050-1062. [CrossRef]

3. Chryss, A.; Fourie, A.B.; Monch, A.; Nairn, D.; Seddon, K.D. Towards an integrated approach to tailings management. J. South. Afr. Inst. Min. Metall. 2012, 112, 965-969.

4. Lebre, É.; Corder, G. Integrating industrial ecology thinking into the management of mining waste. Resources 2015, 4, 765-786. [CrossRef]

5. Wellmer, F.W.; Buchholz, P.; Gutzmer, J.; Hagelüken, C.; Herzig, P.; Littke, R.; Thauer, R.K. Raw Materials for Future Energy Supply; Springer: Berlin, Germany, 2018.

6. Corder, G.D. Insights from case studies into sustainable design approaches in the minerals industry. Miner. Eng. 2015, 76, 47-57. [CrossRef]

7. ICMM. Icmm Sustainable Development Framework; International Council on Mining and Metals: London, UK, 2003; pp. 2-17.

8. UN. Rio Declaration on Environment and Development; Report of the United Nations conference on environment and development; United Nations: Rio de Janerio, Brazil, 3-14 June 1992.

9. GRI. The Global Reporting Initiative (gri) Standards. Available online: https://www.globalreporting.org/ standards (accessed on 13 July 2018).

10. McLellan, B.C.; Corder, G.D.; Giurco, D.; Green, S. Incorporating sustainable development in the design of mineral processing operations - review and analysis of current approaches. J. Clean Prod. 2009, 17, 1414-1425. [CrossRef]

11. Kemp, D.; Owen, J.R.; van de Graaff, S. Corporate social responsibility, mining and "audit culture". J. Clean Prod. 2012, 24, 1-10. [CrossRef]

12. Davis, R.; Franks, D.M. Costs of company-community conflict in the extractive sector. Corp. Soc. Responsib. Initiat. Rep. 2014, 66, 1-56.

13. Franks, D.M.; Davis, R.; Bebbington, A.J.; Ali, S.H.; Kemp, D.; Scurrah, M. Conflict translates environmental and social risk into business costs. Proc. Natl. Acad. Sci. USA 2014, 111, 7576-7581. [CrossRef]

14. Esteves, A.M.; Franks, D.; Vanclay, F. Social impact assessment: The state of the art. Impact Assess. Proj. A 2012, 30, 34-42. [CrossRef]

15. Prenzel, P.V.; Vanclay, F. How social impact assessment can contribute to conflict management. Environ. Impact Assess. Rev. 2014, 45, 30-37. [CrossRef]

16. Lockie, S.; Franettovich, M.; Petkova-Timmer, V.; Rolfe, J.; Ivanova, G. Coal mining and the resource community cycle: A longitudinal assessment of the social impacts of the coppabella coal mine. Environ. Impact Assess. Rev. 2009, 29, 330-339. [CrossRef]

17. Kemp, D.; Vanclay, F. Human rights and impact assessment: Clarifying the connections in practice. Impact Assess. Proj. Apprais. 2013, 31, 86-96. [CrossRef]

18. Owen, J.R.; Kemp, D. Social licence and mining: A critical perspective. Resour. Policy 2013, 38, 29-35. [CrossRef]

19. Franks, D.M.; Boger, D.V.; Côte, C.M.; Mulligan, D.R. Sustainable development principles for the disposal of mining and mineral processing wastes. Resour. Policy 2011, 36, 114-122. [CrossRef]

20. Lottermoser, B.G. Mine Wastes: Characterization, Treatment and Environmental Impacts, 3rd ed.; Springer: Berlin, Germany, 2010. 
21. MEND. Mine Environment Neutral Drainage Manual; Volume 3: Prediction. Mend 5.4.2c; Mine Environment Neutral Drainage (MEND) Program: Vancouver, Canada, 2000.

22. Skousen, J.; Rose, A.; Geidel, G.; Foreman, J.; Evans, R.; Hellier, W. Handbook of Technologies for Avoidance and Remediation of Acid Mine Drainage; West Virginia University: Morgantown, WV, USA, 1998.

23. Jones, S.N.; Cetin, B. Evaluation of waste materials for acid mine drainage remediation. Fuel 2017, 188, 294-309. [CrossRef]

24. Park, J.H.; Edraki, M.; Mulligan, D.; Jang, H.S. The application of coal combustion by-products in mine site rehabilitation. J. Clean Prod. 2014, 84, 761-772. [CrossRef]

25. Davies, M.P. Tailings impoundment failures are geotechnical engineers listening? Geotech. News Vanc. 2002, 20,31-36.

26. MMSD. Report of the Workshop on Finance, Mining and Sustainability: Exploring Sound Investment Decision Processes; Mining, Minerals and Sustainable Development Project (MMSD); International Institute for Environment and Development (IIED): Paris, France, 14-15 January 2002.

27. Ke, X.; Zhou, X.; Wang, X.; Wang, T.; Hou, H.; Zhou, M. Effect of tailings fineness on the pore structure development of cemented paste backfill. Constr. Build. Mater. 2016, 126, 345-350. [CrossRef]

28. Edraki, M.; Huynh, T.; Wightman, E.; Tungpalan, K.; Palaniandy, S. An Integrated Approach to Proactive Tailings Management. In Proceedings of the Tailings and Mine Waste Management for the 21st Century, Sydney, Australia, 27-28 July 2015; The Australasian Institute of Mining and Metallurgy: Sydney, Australia; pp. 323-332.

29. Edraki, M.; Baumgartl, T.; Fletcher, A.; Mulligan, D.R.; Fegan, W.; Munawar, A. Hydrogeochemical Evolution of an Uncapped Gold Tailings Storage Facility. In Proceedings of the Enviromine 2009: First International Seminar on Environmental Issues in the Mining Industry, Santiago, Chile, 30 September-2 October 2009.

30. Edraki, M.; Forsyth, B.; Baumgartl, T.; Bradshaw, D. Geochemistry of tailings and seepage from three tailings storage facilities in australia - uncapped, capped and active tailings. In Proceedings of the Life-of-Mine 2012: Maximizing Rehabilitation Outcomes, Brisbane, Australia, 10-12 July 2012; The Australasian Institute of Mining and Metallurgy: Brisbane, Australia; pp. 269-278.

31. Fall, M.; Adrien, D.; Célestin, J.C.; Pokharel, M.; Touré, M. Saturated hydraulic conductivity of cemented paste backfill. Miner. Eng. 2009, 22, 1307-1317. [CrossRef]

32. Fang, Y.; Gu, Y.; Kang, Q.; Wen, Q.; Dai, P. Utilization of copper tailing for autoclaved sand-lime brick. Constr. Build. Mater. 2011, 25, 867-872. [CrossRef]

33. Argane, R.; Benzaazoua, M.; Hakkou, R.; Bouamrane, A. Reuse of base-metal tailings as aggregates for rendering mortars: Assessment of immobilization performances and environmental behavior. Constr. Build. Mater. 2015, 96, 296-306. [CrossRef]

34. Argane, R.; Benzaazoua, M.; Hakkou, R.; Bouamrane, A. A comparative study on the practical use of low sulfide base-metal tailings as aggregates for rendering and masonry mortars. J. Clean Prod. 2016, 112, 914-925. [CrossRef]

35. Kim, B.J.; Jang, J.G.; Park, C.Y.; Han, O.H.; Kim, H.K. Recycling of arsenic-rich mine tailings in controlled low-strength materials. J. Clean Prod. 2016, 118, 151-161. [CrossRef]

36. Liu, T.Y.; Tang, Y.; Han, L.; Song, J.; Luo, Z.W.; Lu, A.X. Recycling of harmful waste lead-zinc mine tailings and fly ash for preparation of inorganic porous ceramics. Ceram. Int. 2017, 43, 4910-4918. [CrossRef]

37. Taha, Y.; Benzaazoua, M.; Hakkou, R.; Mansori, M. Coal mine wastes recycling for coal recovery and eco-friendly bricks production. Miner. Eng. 2017, 107, 123-138. [CrossRef]

38. Driussi, C.; Jansz, J. Technological options for waste minimisation in the mining industry. J. Clean Prod. 2006, 14, 682-688. [CrossRef]

39. OKTediMining. 2009 Annual Environmental Report. OK Tedi Mining. 2014. Available online: https: //www.oktedi.com/index.php/media-items/reports/environmental/annual-environmental-reports (accessed on 22 March 2019).

40. Bois, D.; Poirier, P.; Benzaazoua, M.; Bussière, B.; Kongolo, M. A feasibility study on the use of desulphurized tailings to control acid mine drainage. C. Bull. 2005, 98, 1.

41. Cropp, A.F.; Goodall, W.R.; Bradshaw, D.J. The influence of textural variation and gangue mineralogy on recovery of copper by flotation from porphyry ore: A review. In Proceedings of the GeoMet 2013: The Second AusIMM International Geometallurgy Conference, Brisbane, Australia, 30 September-2 October 2013. 
42. Bridge, R.; Brosig, D.; Lozano, C.; Laurila, H. Geometallurgy: An. Underutilised Technology; Canadian Institute of Mining, Metallurgy and Petroleum: Quebec, Canada, 2013.

43. Dominy, S.C.; O'Connor, L. Geometallurgy-Beyond conception. In Proceedings of the Third AusIMM International Geometallurgy Conference (GeoMet) 2016, Perth, Australia, 15-17 June 2016; The Australasian Institute of Mining and Metallurgy: Perth, Australia; pp. 3-10.

44. Dunham, S.; Vann, J. Geometallurgy, geostatistics and project value-Does your block model tell you what you need to know. In Proceedings of the Project Evaluation Conference, Melbourne, Australia, 19-20 June 2007; pp. 189-196.

45. Vann, J.; Jackson, J.; Coward, S.; Dunham, S. The geomet curve-A model for implementation of geometallurgy. In Proceedings of the First AusIMM International Geometallurgy (GeoMet) Conference, Brisbane, Australia, 5-7 September 2011.

46. Bye, A.R. Case studies demonstrating value from geometallurgy initiatives. In Proceedings of the First AusIMM International Geometallurgy (GeoMet) Conference, Brisbane, Australia, 5-7 September 2011; Australasian Institute of Mining and Metallurgy: Brisbane, Australia; pp. 9-30.

47. Louwrens, E.; Napier-Munn, T.; Keeney, L. Geometallurgical characterisation of a tailings storage facility-A novel approach. In Tailings and Mine Waste Management for the 21st Century, 27-28 July 2015; Australasian Institute of Mining and Metallurgy: Sydney, Australia, 2015; pp. 125-132.

48. Edraki, M.; Huynh, T.; Baumgartl, T.; Huang, L.; Andrusiewicz, M.; Tungpalan, K.; Tayebi-Khorami, M.; Wightman, E.; Palaniandy, S.; Manlapig, E. Designer tailings: Improving the management of tailings through collaborative research. In Proceedings of the Triennial 8th Australian Workshop on Acid and Metalliferous Drainage, Adelaide, Australia, 29 April-2 May 2014; pp. 173-182.

49. Tungpalan, K.; Manlapig, E.; Andrusiewicz, M.; Keeney, L.; Wightman, E.; Edraki, M. An integrated approach of predicting metallurgical performance relating to variability in deposit characteristics. Miner. Eng. 2015, 71, 49-54. [CrossRef]

50. Tayebi-Khorami, M.; Manlapig, E.; Forbes, E. Relating the mineralogical characteristics of tampakan ore to enargite separation. Miner. Basel 2017, 7, 77. [CrossRef]

51. Report of the World Commission on Environment and Development: Our Common Future; General Assembly Resolution 42/187; United Nations: Rio de Janerio, Brazil, 11 December 1987.

52. WEF. Mining \& Metals in a Sustainable World 2050; World Economic Forum: Geneva, Switzerland, 2015; Available online: http://www3.weforum.org/docs/WEF_MM_Sustainable_World_2050_report_2015.pdf (accessed on 22 March 2019).

53. Unger, C. Legacy issues and abandoned mines. In Mining in the Asia-Pacific, the Political Economy of the Asia Pacific; Callaghan, T., Graetz, G., Eds.; Springer: Berlin, Germany, 2017; pp. 333-369.

54. Corder, G.D.; McLellan, B.C.; Green, S.R. Delivering solutions for resource conservation and recycling into project management systems through susop (r). Miner. Eng. 2012, 29, 47-57. [CrossRef]

55. Lèbre, É.; Corder, G.; Golev, A. The role of the mining industry in a circular economy: A framework for resource management at the mine site level. J. Ind. Ecol. 2017, 21, 662-672. [CrossRef]

56. Corder, G.D.; Golev, A.; Fyfe, J.; King, S. The status of industrial ecology in australia: Barriers and enablers. Resources 2014, 3, 340-361. [CrossRef]

57. Wang, Y.M. China recycling economy development and its mineral resources' sustainable development. Metal. Mine 2005, 2, 1-3.

58. Golev, A.; Lebre, E.; Corder, G. The contribution of mining to the emerging circular economy. AusIMM Bull. 2016, 2016, 30-32.

59. Edraki, M.; Baumgartl, T.; Manlapig, E.; Bradshaw, D.; Franks, D.M.; Moran, C.J. Designing mine tailings for better environmental, social and economic outcomes: A review of alternative approaches. J. Clean Prod. 2014, 84, 411-420. [CrossRef]

60. Forum for the Future. Circular Economy Business Model Toolkit; Forum for the Future, Unilever; 2016; Available online: https://www.forumforthefuture.org/project/circular-economy-business-model-toolkit/ overview (accessed on 22 March 2019).

61. Genex Power. Kidston Renewable Energy Hub. Available online: https://www.abc.net.au/news/2018-06-20/ kidston-renewable-energy-hub/9890600 (accessed on 22 March 2019). 
62. Barker, E. Century Mine Waste Dam to Become World's Fourth-Largest Zinc Operation Following Rehabilitation. Available online: https://www.abc.net.au/news/rural/2018-09-17/century-mine-from-wastedam-to-zinc-mine/10253334 (accessed on 15 March 2019).

63. Elshkaki, A.; Graedel, T.E.; Ciacci, L.; Reck, B.K. Copper demand, supply, and associated energy use to 2050. Glob. Environ. Chang. 2016, 39, 305-315. [CrossRef]

(C) 2019 by the authors. Licensee MDPI, Basel, Switzerland. This article is an open access article distributed under the terms and conditions of the Creative Commons Attribution (CC BY) license (http://creativecommons.org/licenses/by/4.0/). 